\title{
Intrapulmonary mature cystic teratoma of the lung: case report of a rare entity
}

\author{
Parviz Mardani ${ }^{1,2}$, Reyhaneh Naseri ${ }^{3}$, Armin Amirian ${ }^{1,2}$, Reza Shahriarirad ${ }^{1,3}$, Mohammad Hossein Anbardar ${ }^{4}$, \\ Damoun Fouladi ${ }^{1,3^{*}}$ (i) and Keivan Ranjbar ${ }^{1,3}$
}

\begin{abstract}
Background: Intrapulmonary teratoma (IPT) is a rare type of extra gonadal teratoma which often presents with non-specific symptoms and can be misdiagnosed as other diseases. Here we report a patient with IPT which was initially misdiagnosed as lung hydatid cyst versus abscess.
\end{abstract}

Case presentation: We report an intrapulmonary teratoma in a 27-year-old female presenting with persistent chest pain and dyspnea since a few years prior to her admission with associated symptoms of cough and fever. Chest $x-$ ray only showed left side massive pleural effusion and computed tomography scan of the lungs was suggestive of hydatid cyst or a lung abscess. She underwent lobectomy and postoperative histopathological study revealed IPT as the final diagnosis.

Conclusion: Due to the non-specific symptoms and rarity, IPT can be easily misdiagnosed at first. It is essential that physicians take into account the possibility of IPT when approaching a new case of lung mass.

Keywords: Teratoma, Lung, Case report, Pathology, Surgery

\section{Background}

Teratomas are benign germ cell tumors that are mostly found in the gonads with a low malignant transformation potency [1-3]. Extra-gonadal germ cell tumors are considered rare with mediastinum as the most common site [4], but can also arise in other areas such as the head and neck [5], retroperitoneum, sacrococcygeal region and on rare occasions the lung, which is considered as an intrapulmonary teratoma (IPT) [6]. In this study, we present a rare case of a benign intrapulmonary teratoma in a 27-year-old female involving the left upper lobe of the lung, which was successfully treated by lobectomy with no recurrence during a 6 year follow-up.

\footnotetext{
* Correspondence: damoun.fld@gmail.com

${ }^{1}$ Thoracic and Vascular Surgery Research Center, Shiraz University of Medical Science, Shiraz, Iran

${ }^{3}$ Student Research Committee, Shiraz University of Medical Sciences, Shiraz, Iran

Full list of author information is available at the end of the article
}

\section{Case presentation}

A 27-year-old female visited our clinic with an unremarkable past medical history, with the chief complaint of progressive dyspnea and chest pain since 2 weeks prior to admission, which was recently accompanied by non-productive cough, chills, fever, and orthopnea. She also reported a mild, episodic, and occasionally pleuritic chest pain that radiated to back and left upper extremity. She denied any nausea, vomiting, rashes, joint pain, weight loss, or a history of smoking. She also reported a previous admission a few years ago due to dyspnea and chest pain in which after normal cardiac evaluation, was discharged with no established diagnosis.

On physical examination, the patient was febrile $\left(38.3^{\circ} \mathrm{C}\right.$ orally) and breathing sound was decreased in lower two-third of the left lung. Other systemic exams were unremarkable. The patient underwent radiological chest evaluation, in which chest X-ray revealed massive left side pleural effusion with no apparent focal opacities. On admission, routine blood investigations including 
renal and liver function tests were within normal limits, apart from white blood cell count that showed leukocytosis $\left(14.8 \times 10^{3}\right)$. On the suspicion of rheumatologic disorders, rheumatoid factors were evaluated which were all normal. Subsequently, a chest computed tomography (CT) scan also revealed pleural effusion, which along with previous findings, provided us with the impression of empyema. Therefore, a pleural drainage needle catheter was inserted but due to insufficient drainage, it was replaced with a chest tube.

Considering patients persistent fever and CT scan revelations, a provisional diagnosis of hydatid cyst versus lung abscess was made, and she was administered different antibiotics (ceftriaxone $1 \mathrm{~g}$ intravenous every $12 \mathrm{~h} /$ clindamycin $600 \mathrm{mg}$ intravenous every $8 \mathrm{~h} \mathrm{/} \mathrm{Imipenem}$ $500 \mathrm{mg}$ intravenous every $6 \mathrm{~h}$ ) and Albendazole (400 mg orally, daily), however, the symptoms did not alleviate and due to the possibility of hydatid cyst, intensive procedures such as aspiration and biopsy was avoided and surgical interventions to remove the lesion was suggested for treatment. Furthermore, abdominopelvic ultrasonography was done to rule out possible liver, retroperitoneal, and gonadal mass, which no significant findings were detected.

The patient was operated under general anesthesia. Due to the severe adhesions caused by the recurrent previous infections, the operation changed from up position thoracoscopy to posterolateral thoracotomy. While exploring the pleural cavity, a grayish multi-lobulated firm intrapulmonary cystic mass $(13 \times 11 \times 4 \mathrm{~cm})$ was detected in the left upper lobe which was filled with hair and keratinized material. Based on the severe involvement and the retraction of the left upper lobe, left upper lobectomy was carried out.

The specimen was collected from the lesion and the pleura for microscopic pathological evaluation. The gross examination of the operated specimen showed the upper lobe of the lung attached to a lobulated grayish cystic mass measuring $13 \times 11 \times 4 \mathrm{~cm}$. Cut sections of the mass revealed unilocular cystic lesion filled with hair and waxy material. Microscopic sections showed the cystic lesion consisted of endodermal, ectodermal, and mesodermal components. Pancreatic tissue, mucinous epithelium, respiratory epithelium, epidermal tissue with sebaceous glands, adipose tissue, smooth muscle, and cartilage were identified in multiple microscopic sections (Figs. 1, 2, 3). Non-tumoral tissue showed pneumonia and pleural excision showed fibrinoid degeneration. No immature or malignant component was identified and the diagnosis of mature cystic teratoma was confirmed.

Based on the patients' surgical and histopathological findings, a final diagnosis of intrapulmonary mature cystic teratoma was achieved and the patient was discharged after 8 days with an uneventful post-op course. Follow up during the next years showed no sign of recurrence and a normal chest x-ray (Fig. 4).

\section{Discussion and conclusion}

In this study, we presented a rare clinical case of IPT in a 27-year-old female involving the left upper lobe of the lung which presented with chest pain, dyspnea, lowgrade fever, and dry cough. Teratomas are germinal cell

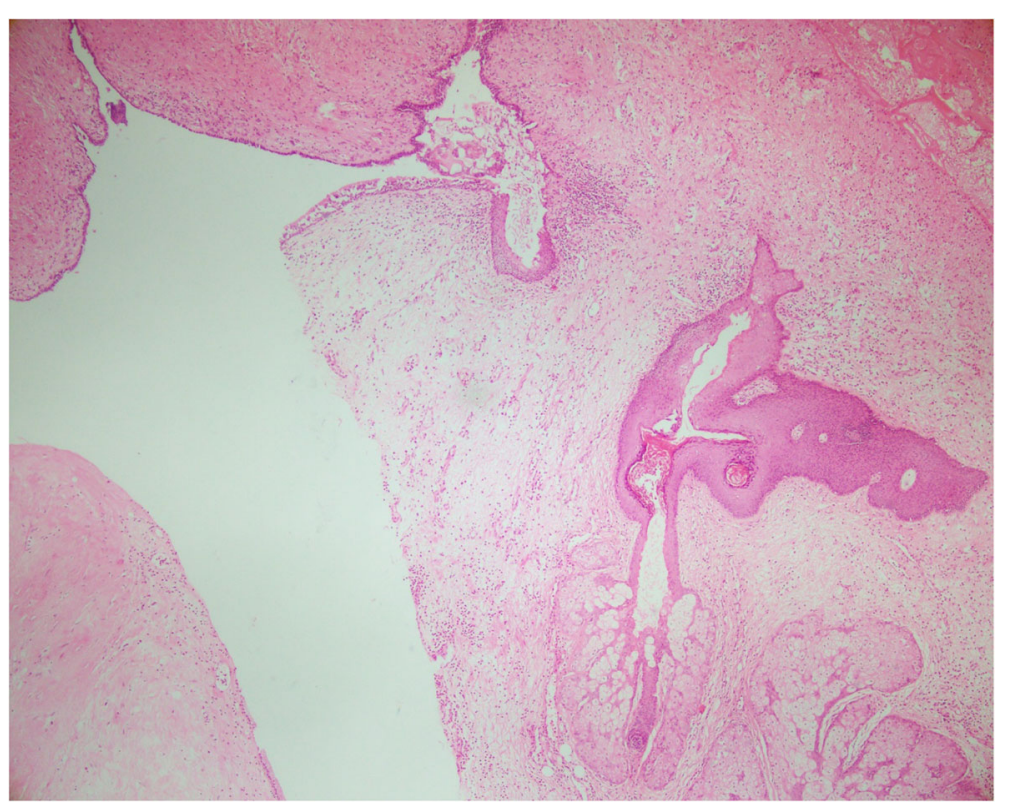

Fig. 1 Microscopic section shows low power view of mature cystic teratoma consist of skin tissue, sebaceous gland and respiratory epithelium. (Hematoxyline and Eosin, $\times 40$ ) 


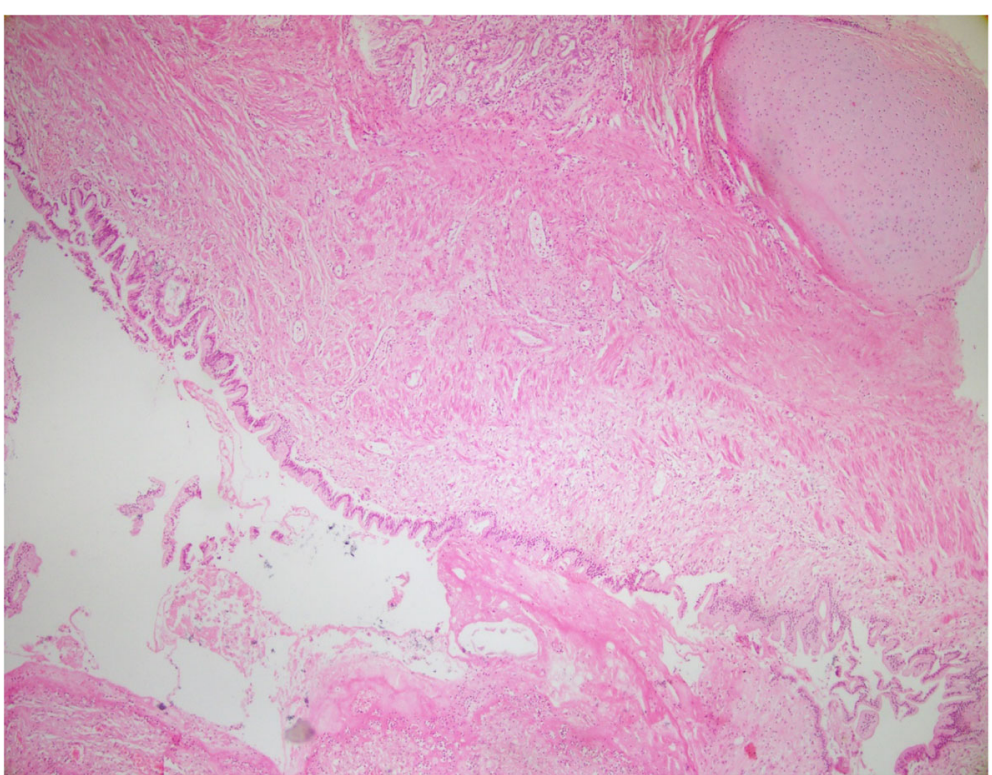

Fig. 2 Microscopic section shows low power view of mature cystic teratoma consist of mature cartilage and mucinous epithelium. (Hematoxyline and Eosin, $\times 40$ )

tumors that are mostly present in gonads but can also be seen in extragonadal tissues [7]. IPT as a type of extragonadal teratoma is considered extremely rare, which can occur at any age but commonly due to their slow growth and voluminosity of the lung, presents mostly at the 3rd decade of life, similar to our presented case [8]. Regarding the tumor size, a review by Iwasaki et al. reported that the size varies in different cases, ranging from few centimeters up to $30 \mathrm{~cm}$ on the largest diameter [9].

Teratomas are usually considered benign tumors but in ovaries in $2 \%$ of the cases, they can undergo a malignant transformation [3]. until 2012, only 8 cases of malignant IPT have been reported. All the cases were male and the prognosis was generally poor with patients having a few days to months to live after presenting with

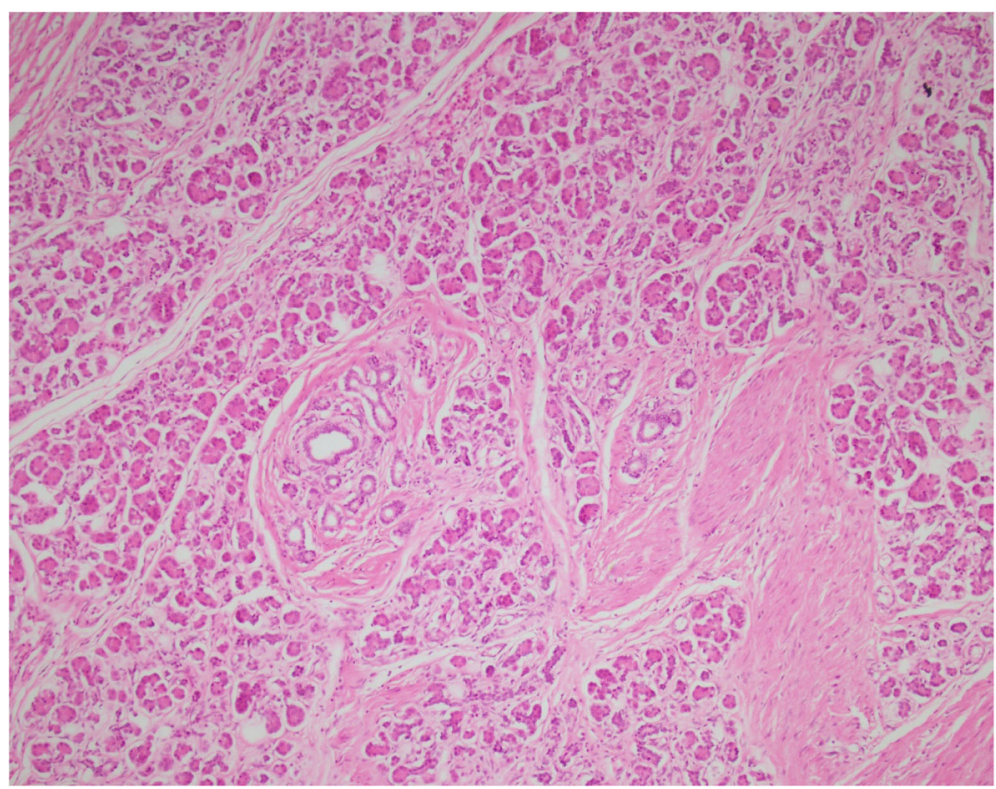

Fig. 3 Microscopic section shows pancreatic tissue. (Hematoxyline and Eosin, $\times 100$ ) 


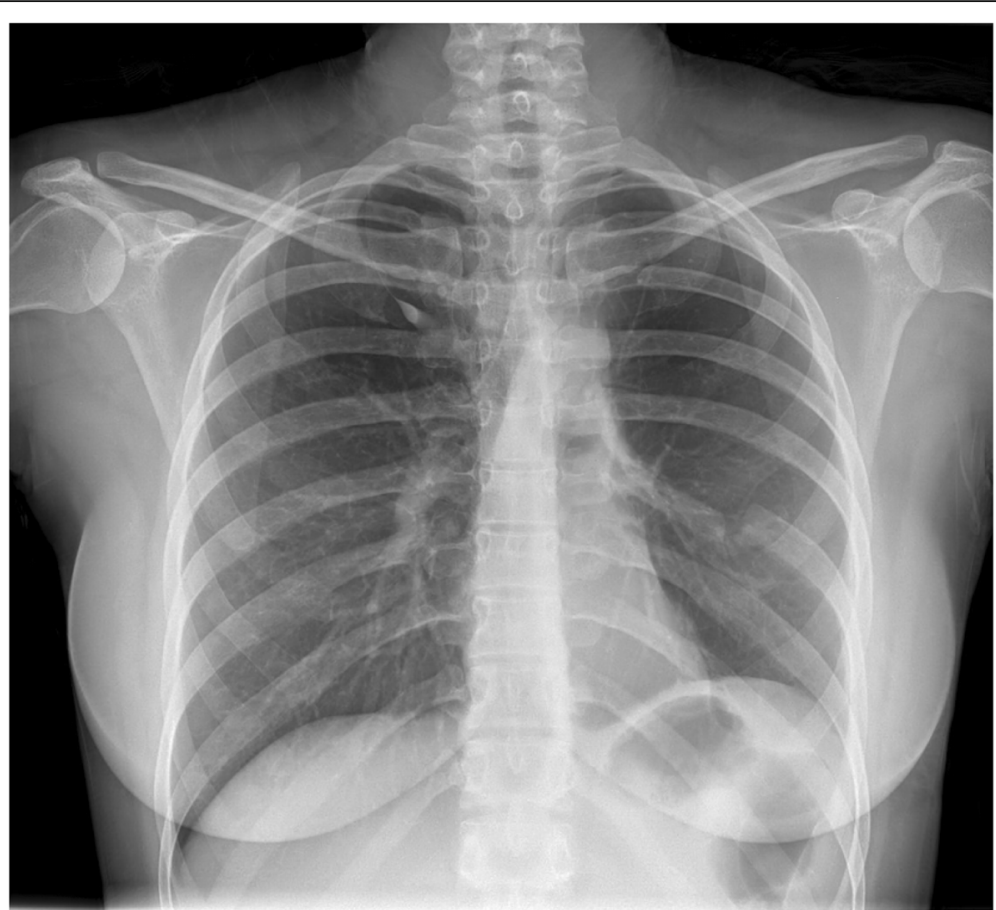

Fig. 4 Follow-up chest $x$-ray of a 27-year-old female 4 month after left upper lobe lobectomy

symptoms. The malignant trasnformation can happen in any type of tissue present in the teratoma and is potensialy capable of metastasis to lymphnodes and other regions [1].

Previous studies have proved that there is an equal distribution of IPT by sex for men and women [8]. Due to indeterminate reasons, the predominant location of IPT is the upper lobe as similar to our case [10]. Patients become symptomatic due to the compression of the surrounding structures.

In our case, the patient presented with chest pain, dyspnea, fever, and dry cough. Similar studies have shown the common presenting clinical symptoms of IPT include chest pain as the most common presentation, fever, cough, dyspnea, and also hallmarks of pneumonia or bronchiectasis [8]. Trichoptysis (expectoration of hair) is a rare pathognomonic symptom that provides strong evidence in favor of IPT and usually occurs in the late course of the disease followed by tumor invasion into the tracheobronchial tree [11].

Reports from other studies have shown that laboratory tests are usually within normal limits [12, 13], which is aligned with our case, except for leukocytosis that along with symptoms such as fever and cough that lead us to the diagnosis of infections and pneumonia. In a similar study on a 32-year-old male who was diagnosed with IPT, lab data showed leukocytosis and on chest $x$-ray patient had a large pleural effusion in the lower two-third of the right lung which culture of the thoracentesis fluid grew Salmonella enteritidis [14]. Due to the severe adhesions during the operation, it's possible that the IPT predisposed the patient to recurrent pneumonia of the left lung during the years. The fever and leukocytosis could be associated with the concomitant pneumonia of the patient.

Based on radiological findings, in the majority of the cases, cystic lesions often with focal calcification are reported [15] but in some cases, chest $\mathrm{x}$ rays might be of non-diagnostic value, such as in the present study especially if calcified tissue such as bone and teeth are not present. Chest CT is considered as a standard technique of diagnosis as it reveals the exact location, extension, and the nature of the mass; however, it could also demonstrate nonspecific findings [12]. Studies have shown a lobulated cystic structure with peripheral translucency is distinctive for the diagnosis of teratoma in CT scans. Furthermore, if air is observed in the mass, it could suggest the connection of the cyst to the bronchial tree [15].

The preoperative diagnosis in our case was in favor of empyema along with the possibility of hydatid cyst or lung abscess. Based on the nature of the tumor and symptoms, other possible differential diagnoses 
Table 1 Clinical and radiological comparison of intrapulmonary teratoma, hydatid cyst of lung, and lung abscess

\begin{tabular}{|c|c|c|c|}
\hline & Radiography & Signs and Symptoms & Involvement Features \\
\hline Intrapulmonary Teratoma & $\begin{array}{l}\text { - Typically cystic masses often with } \\
\text { focal calcification and peripheral } \\
\text { translucency } \\
\text { - Air fluid level is suggestive of } \\
\text { bronchial communication if } \\
\text { present }[9,19]\end{array}$ & $\begin{array}{l}\text { - Chest pain } \\
\text { - Hemoptysis } \\
\text { - Cough } \\
\text { - Trichoptysis (most specific) [19] }\end{array}$ & $\begin{array}{l}\text { - Location: left upper lobe [9] } \\
\text { - Unilateral [19] }\end{array}$ \\
\hline Hydatid cyst & $\begin{array}{l}\text { - Typically, a well-defined } \\
\text { homogenous radio-opacity } \\
\text { - Air fluid level in case of a } \\
\text { complicated cyst [20] }\end{array}$ & $\begin{array}{l}\text { - Usually asymptomatic for many years } \\
\text { - Chest pain } \\
\text { - Dyspnea } \\
\text { - Dry cough } \\
\text { - Hemoptysis [20] }\end{array}$ & $\begin{array}{l}\text { - Location: lower lobes specially } \\
\text { the right basal lobe } \\
\text { - Bilateral in } 20 \% \text { of the cases [20] }\end{array}$ \\
\hline $\begin{array}{l}\text { Acute Lung abscess } \\
\text { (less than } 6 \text { week) }\end{array}$ & $\begin{array}{l}\text { - Usually circumscribed with not } \\
\text { so well-defined surrounding to } \\
\text { lung parenchyma } \\
\text { - Air fluid level mostly present [21] }\end{array}$ & $\begin{array}{l}\text { - Productive Cough } \\
\text { - Fever } \\
\text { - Night sweats [21] }\end{array}$ & $\begin{array}{l}\text { - Location: posterior segments of the } \\
\text { upper lobes and the superior } \\
\text { segments of the lower lobes (if } \\
\text { caused by aspiration) [21] } \\
\text { - Usually unilateral [22] }\end{array}$ \\
\hline Chronic lung abscess & $\begin{array}{l}\text { - Usually irregular star-like shape } \\
\text { with well-defined surrounding } \\
\text { to lung parenchyma } \\
\text { - Air fluid level mostly present [21] }\end{array}$ & $\begin{array}{l}\text { - Productive Cough } \\
\text { - Fever } \\
\text { - Night sweats } \\
\text { - Weight loss [21] }\end{array}$ & $\begin{array}{l}\text { - Location: posterior segments of the } \\
\text { upper lobes and the superior } \\
\text { segments of the lower lobes (if } \\
\text { caused by aspiration) [21] } \\
\text { - Usually unilateral [22] }\end{array}$ \\
\hline
\end{tabular}

include ruptured hydatid cysts, fungal masses, lung abscess, pulmonary hamartoma, bronchogenic cyst, adenomatoid cystic malformation, intrapulmonary cystic lymphangioma, mediastinal teratoma, and pulmonary leiomyoma could also be considered [12, 13, 1619]. In the discussed case, the preoperative CT scan implicated a misdiagnosis of a hydatid cyst in which the patient underwent anti-hydatidosis treatment. However, findings could be misleading if the diseases present with less common signs and symptoms.

Table 1 demonstrates a comparison of some typical features of the IPT case in our study with the possible differential diagnosis [10, 20-23].

Rupture of the tumor, hemoptysis, airway compression, and malignant transformation are the complications of IPT if remains untreated [18, 24]. Surgery is considered as the optimal treatment and postoperative histopathological analysis provides the definitive diagnosis in which squamous epithelium with abundant keratin, connective tissues, components of fat tissue, calcifications such as teeth or bone, floating masses of hair and endometrial tissue could be observed [15, 25]. Similar characteristics have been presented in this case.

In conclusion, the preoperative diagnosis of IPT is not always possible and is usually misdiagnosed at first because of its rarity, non-specific and vague symptoms, normal laboratory results, and indistinguishable chest radiography findings. Initial diagnosis can be established based on a CT scan which can demonstrate calcification, cavitation, and peripheral translucency. Complete resection and surgery are considered as its gold standard curative treatment modality to avoid complications and malignant transformation. Therefore, prompt diagnosis and suitable treatment should be immediately performed for these patients to avoid significant and lifethreatening complications.

\section{Abbreviations}

IPT: Intrapulmonary teratoma; CT: Computed tomography; IV: Intravenous

\section{Acknowledgments}

None to declare.

\section{Authors' contributions}

PM designed the study. RN and DF collected the data. DF and RS drafted the manuscript. MA reviewed the pathological slide and provided the microscopic sections. AA and KR revised and proofread the manuscript. All authors read and approved the final version of the manuscript.

\section{Funding}

No source of funding.

Availability of data and materials

Data of the patient can be requested from authors. Please write to the corresponding author if you are interested in such data.

\section{Ethics approval and consent to participate}

The present study was approved by the Medical Ethics Committee of Shiraz University of Medical Sciences. The purpose of this report was completely explained to the patient and written inform consent was obtained from the patient.

\section{Consent for publication}

Written informed consent for publication of the patient's clinical details and pathologic images was obtained from the patient. A copy of the consent form is available for review by the Editor of this journal.

\section{Competing interests}

The authors declare that they have no competing interests.

\section{Author details}

${ }^{1}$ Thoracic and Vascular Surgery Research Center, Shiraz University of Medical Science, Shiraz, Iran. ${ }^{2}$ Department of Surgery, Shiraz University of Medical 
Sciences, Shiraz, Iran. ${ }^{3}$ Student Research Committee, Shiraz University of Medical Sciences, Shiraz, Iran. ${ }^{4}$ Department of Pathology, Namazee Teaching Hospital, School of Medicine, Shiraz University of Medical Sciences, Shiraz, Iran.

Received: 29 May 2020 Accepted: 7 September 2020

Published online: 14 September 2020

\section{References}

1. Giunchi F, Segura JJ. Primary malignant teratoma of lung: report of a case and review of the literature. Int J Surg Pathol. 2012;20(5):523-7.

2. Choi JS, Bae YC, Lee JW, Kang GB. Dermoid cysts: epidemiology and diagnostic approach based on clinical experiences. Arch Plast Surg. 2018; 45(6):512

3. Bal A, Mohan $H$, Singh $S B$, Sehgal A. Malignant transformation in mature cystic teratoma of the ovary: report of five cases and review of the literature. Arch Gynecol Obstet. 2007;275(3):179-82.

4. Yalagachin $\mathrm{GH}$. Anterior mediastinal teratoma-a case report with review of literature. Indian J Surg. 2013;75(1):182-4.

5. Lack EE. Extragonadal germ cell tumors of the head and neck region: review of 16 cases. Hum Pathol. 1985;16(1):56-64.

6. Gatcombe HG, Assikis V, Kooby D, Johnstone PA. Primary retroperitoneal teratomas: a review of the literature. J Surg Oncol. 2004;86(2):107-13.

7. Badar F, Yasmeen S, Afroz N, Khan N, Azfar SF. Benign mediastinal teratoma with intrapulmonary and bronchial rupture presenting with recurrent hemoptysis. Iran J Radiol. 2013;10(2):86.

8. Asano S, Hoshikawa Y, Yamane Y, Ikeda M, Wakasa H. An intrapulmonary teratoma associated with bronchiectasia containing various kinds of primordium: a case report and review of the literature. Virchows Arch. 2000; 436(4):384-8.

9. Iwasaki T, luchi K, Matsumura A, Sueki H, Yamamoto S, Mori T. Intrapulmonary mature teratoma. Jpn J Thorac Cardiovasc Surg. 2000;48(7): 468-72

10. Dasbaksi K, Haldar S, Mukherjee K, Chakraborty U, Majumdar P, Mukherjee P. Intrapulmonary teratoma: report of a case and review of literature. Asian Cardiovasc Thorac Ann. 2016;24(6):574-7.

11. Agarwal R, Srinivas R, Saxena AK. Trichoptysis due to an intrapulmonary teratoma. Respir Care. 2007;52(12):1779-81.

12. Macht M, Mitchell JD, Cool C, Lynch DA, Babu A, Schwarz MI. A 31-year-old woman with hemoptysis and an intrathoracic mass. Chest. 2010;138(1):2139.

13. Scinico M, Ogunnaike R, Inigo-Santiago L. Intrapulmonary Teratoma Causing S. Enteritidis Pneumonia. B60 BACTERIAL AND VIRAL INFECTION CASES. Ann Am Thorac Soc. 2020;201:A3893. 243-6.

14. Scinico M, Ogunnaike R, Inigo-Santiago L. Intrapulmonary Teratoma Causing S. Enteritidis Pneumonia. B60 BACTERIAL AND VIRAL INFECTION CASES. Ann Am Thorac Soc. 2020;201:A3893.

15. Bernot JM, Haeusler KA, Lisanti CJ, Brady RO, Ritchie BL. Mature cystic teratoma: AIRP best cases in radiologic-pathologic correlation. RadioGraphics. 2017:37(5):1401-7.

16. Ditah C, Templin T, Mandal R, Pinchot JW, Macke RA. Isolated intrapulmonary teratoma. J Thorac Cardiovasc Surg. 2016;6(152):e129-e31.

17. Saha TK, Roy A, Chattopadhyay A, Roy B, Mondal G. Giant intrapulmonary teratoma in an infant. Hell Cheirourgike. 2015;87(2):185-7.

18. Sawant AC, Kandra A, Narra SR. Intrapulmonary cystic teratoma mimicking malignant pulmonary neoplasm Case Rep. 2012;2012:bcr0220125770.

19. Barreto MM, Valiante PM, Zanetti G, Boasquevisque CHR, Marchiori E. Intrapulmonary mature teratoma mimicking a fungus ball. Lung. 2015; 193(3):443-5.

20. Saini ML, Krishnamurthy S, Kumar RV. Intrapulmonary mature Teratoma. Diagn Pathol. 2006;1(1):38.

21. Garg MK, Sharma M, Gulati A, Gorsi U, Aggarwal AN, Agarwal R, et al. Imaging in pulmonary hydatid cysts. World J Radiol. 2016;8(6):581-7.

22. Kuhajda I, Zarogoulidis K, Tsirgogianni K, Tsavlis D, Kioumis I, Kosmidis C, et al. Lung abscess-etiology, diagnostic and treatment options. Ann Transl Med. 2015:3(13):183

23. Moreira JS, Camargo JJ, Felicetti JC, Goldenfun PR, Moreira A, Porto NS. Lung abscess: analysis of 252 consecutive cases diagnosed between 1968 and 2004. J Bras Pneumol. 2006;32(2):136-43.

24. Rana SS, Swami N, Mehta S, Singh J, Biswal S. Intrapulmonary teratoma: an exceptional disease. Ann Cardiothorac Surg. 2007;83(3):1194-6.
25. Ueno T, Tanaka YO, Nagata M, Tsunoda H, Anno I, Ishikawa S, et al. Spectrum of germ cell tumors: from head to toe. Radiographics. 2004;24(2): 387-404.

\section{Publisher's Note}

Springer Nature remains neutral with regard to jurisdictional claims in published maps and institutional affiliations.
Ready to submit your research? Choose BMC and benefit from:

- fast, convenient online submission

- thorough peer review by experienced researchers in your field

- rapid publication on acceptance

- support for research data, including large and complex data types

- gold Open Access which fosters wider collaboration and increased citations

- maximum visibility for your research: over $100 \mathrm{M}$ website views per year

At $\mathrm{BMC}$, research is always in progress.

Learn more biomedcentral.com/submissions 